\title{
UPAYA PENINGKATAN PENGETAHUAN ENERGI TERBARUKAN DI SMK MA'ARIF NU TALANG KOTA TEGAL
}

\author{
Mukhamad Khumaidi Usman ${ }^{1}$, Syarifudin $^{2}$, Sigit Setijo Budi ${ }^{3}$ \\ 1,2,3 Program Studi DIII Teknik Mesin Politeknik Harapan Bersama \\ Email : \\ ${ }^{1}$ khumaidioesman@gmail.com, ${ }^{2}$ masudinsyarif88@gmail.com ${ }^{3}$ Seti08405@gmail.com
}

\begin{abstract}
ABSTRAK
Berkurangnya produksi energi fosil terutama minyak bumi serta komitmen global dalam pengurangan emisi gas rumah kaca, mendorong Pemerintah untuk meningkatkan peran energi baru dan terbarukan secara terus menerus sebagai bagian dalam menjaga ketahanan dan kemandirian energi. Sesuai PP No. 79 Tahun 2014 tentang Kebijakan Energi Nasional, target bauran energi baru dan terbarukan pada tahun 2025 paling sedikit $23 \%$ dan $31 \%$ pada tahun 2050. Daerah kota tegal memiliki garis pantai sekitar 10,2 Km yang belum dimanfaatkan untuk energi listrik, tujuan dari sosialisai ini adalah agar siswa mengenal potensi yang ada disekitar untuk bisa dijadikan energi listrik yang ramah lingkungan. Tujuan untuk memberikan pengetahuan akan energi terbarukan salah satunya pemanfaatan energi matahari, Hasil pengabdian pada masyarakat dalam bentuk Iptek bagi Masyarakat (IbM) yang telah dilaksanakan terdapat peningkatan pengetahuan siswa SMK tentang konversi energi terbarukan dan siswa mampu mempraktikkan instalasi panel surya serta mampu mempraktikkan penggunaan alat ukur arus dan tegangan yang keluar dari panel surya sehingga bisa membuat instalasi panel surya sesuai dengan kebutuhan.
\end{abstract}

\section{Kata Kunci : Energi Listrik, Energi Matahari, Panel Surya}

\section{PENDAHULUAN}

Berkurangnya produksi energi fosil terutama minyak bumi serta komitmen global dalam pengurangan emisi gas rumah kaca, mendorong Pemerintah untuk meningkatkan peran energi baru dan terbarukan secara terus menerus sebagai bagian dalam menjaga ketahanan dan kemandirian energi. Sesuai PP No. 79 Tahun 2014 tentang Kebijakan Energi Nasional, target bauran energi baru dan terbarukan pada tahun 2025 paling sedikit $23 \%$ dan $31 \%$ pada tahun 2050 . Indonesia mempunyai potensi energi baru terbarukan yang cukup besar untuk mencapai target bauran energi primer tersebut, seperti terlihat pada Tabel 1.1.

\begin{tabular}{|l|l|}
\hline Jenis Energi & Potensi \\
\hline Surya & $207,8 \mathrm{Gwp}$ \\
\hline Angin & $60,6 \mathrm{Gw}$ \\
\hline Air & $94,3 \mathrm{Gw}$ \\
\hline Panas Bumi & $28,5 \mathrm{Gw}$ \\
\hline Bioenergi & $32,6 \mathrm{Gw}$ \\
\hline Energi Laut & $17,9 \mathrm{Gw}$ \\
\hline
\end{tabular}

Minimnya pemanfaatan EBT untuk ketenagalistrikan disebabkan masih relatif tingginya harga produksi pembangkit berbasis EBT, sehingga sulit bersaing dengan pembangkit fosil terutama batubara. Selain itu, kurangnya dukungan industri dalam negeri terkait komponen pembangkit energi terbarukan serta masih sulitnya mendapatkan pendanaan berbunga rendah, juga menjadi penyebab terhambatnya pengembangan energi terbarukan. Pemanfaatan EBT pada sektor 
transportasi terutama biodiesel mulai berkembang cepat sejalan dengan pelaksanaan kebijakan mandatori $\mathrm{BBN}$ yang mengamanatkan campuran BBN ke BBM sebesar 20\% (B20) pada sektor transportasi. Perkembangan produksi, ekspor dan pemanfaatan biodiesel.

Mengapa perlu memaksimalkan energi terbarukan

\begin{tabular}{|c|c|c|}
\hline Parameter & $\begin{array}{l}\text { Energi } \\
\text { Terbarukan }\end{array}$ & $\begin{array}{l}\text { Energi } \\
\text { Fosil }\end{array}$ \\
\hline \multicolumn{3}{|l|}{ Security } \\
\hline \begin{tabular}{l}
\multicolumn{2}{l}{ Ketersediaan } \\
Energi Jangka \\
Pendek
\end{tabular} & Intermittent & $\begin{array}{l}\text { Lebih } \\
\text { Continue }\end{array}$ \\
\hline \begin{tabular}{l}
\multicolumn{2}{l}{ Ketersediaan } \\
Energi Jangka \\
Panjang
\end{tabular} & Terjamin & $\begin{array}{l}\text { Tak } \\
\text { Terjamin }\end{array}$ \\
\hline $\begin{array}{l}\text { Ketersediaan } \\
\text { Terhadap } \\
\text { Dinamika }\end{array}$ & Rentan & $\begin{array}{l}\text { Kurang } \\
\text { Rentan }\end{array}$ \\
\hline \multicolumn{3}{|l|}{ Keekonomian } \\
\hline $\begin{array}{ll}\text { Biaya } & \text { Jangka } \\
\text { Pendek } & \\
\end{array}$ & Lebih Tinggi & $\begin{array}{l}\text { Lebih } \\
\text { Rendah }\end{array}$ \\
\hline $\begin{array}{ll}\text { Biaya } & \text { Jangka } \\
\text { Panjang } & \\
\end{array}$ & $\begin{array}{l}\text { Makin } \\
\text { Murah }\end{array}$ & $\begin{array}{l}\text { Makin } \\
\text { Mahal }\end{array}$ \\
\hline $\begin{array}{l}\text { Kerentanan } \\
\text { Terhadap } \\
\text { Dinamika }\end{array}$ & Rentan & $\begin{array}{l}\text { Kurang } \\
\text { Rentan }\end{array}$ \\
\hline \multicolumn{3}{|l|}{ Lingkungan } \\
\hline Emisi & Lebih Bersih & $\begin{array}{l}\text { Tidak } \\
\text { Bersih } \\
\end{array}$ \\
\hline $\begin{array}{l}\text { Benefit Terhadap } \\
\text { Ekonomi } \\
\text { masyarakat }\end{array}$ & Lebih Tinggi & $\begin{array}{l}\text { Lebih } \\
\text { Rendah }\end{array}$ \\
\hline Sustainability & $\begin{array}{l}\text { Lebih } \\
\text { sustain }\end{array}$ & $\begin{array}{l}\text { Tidak } \\
\text { sustain }\end{array}$ \\
\hline
\end{tabular}

Energi Terbarukan (EBT) dapat di klasifikasikan menjadi bagi 2 berdasarkan sifat pasokan dayanya yaitu intermiten dan primer. Intermiten adalah energi yang tidak dapat memberikan daya $24 \mathrm{jam} / \mathrm{sehari}$ atau tidak secara kontinyu seperti Angin dan Surya. Sementara Primer adalah yang sifatanya dapat di andalkan untuk mensuplai daya secara kontinyu 24 jam/sahari seperti : Air, Panas Bumi, Biomassa dan Nuklir.

Daerah kota tegal memiliki garis pantai sekitar 10,2 Km yang belum dimanfaatkan untuk energi listrik, tujuan dari sosialisai ini adalah agar siswa mengenal potensi yang ada disekitar untuk bisa di jadikan energi listrik yang ramah lingkungan, Salah satunya perubahan energi matahari menjadi energi listrik. Energi matahari ini sangat sederhana dalam proses pengaplikasiannya seperti pada gambar berikut
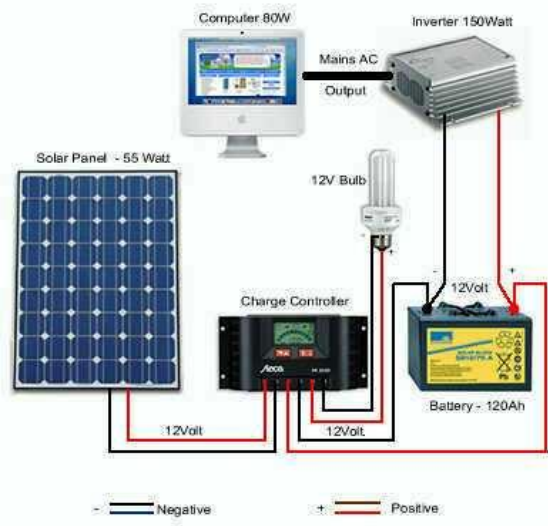

Gambar 1.Rangkaian Instalasi Pembangkit Listrik Tenaga Surya

Masyarakat di kota tegal sendiri khususnya di SMK $\mathrm{Nu}$ Maarif belum mengetahui cara kerja dari energi terbarukan, sehingga belum menerapkan penggunaan energi terbarukan, maka perlunya sosialisai untuk pemanfaatan energi terbarukan yang ada di sekitar. Tujuan dari pengabdian kepada masyarakat ini adalah untuk memberikan pengetahuanakan energi terbarukan salah satunya pemanfaatan energi matahari, adapun manfaatnya yaitu siswa mengenal pemanfaatan energimatahari dan dapat memahami cara instalasi panael surya.

Berdasarkan observasi dan diskusi langsung dengan mitra didapatkan beberapa permasalahan yang dihadapi yaitu: Mitra belum mengenalkan pengetahuan energi terbarukan secara detail. Mereka belum mengetahui dampak penggunaan energi fosil dan manfaat penggunaan energi terbarukan serta teknologi energi terbarukan.

Oleh karena itu berdasarkan hasil analisis situasi dan diskusi dengan mitra tersebut dapat dirumuskan beberapa masalah, yaitu : 
1. Siswa belum mengetahui potensi apa saja yang bisa dimanfaatkan untuk energi terbarukan

2. Siswa belum menggetahui dampak penggunaan energi fosil dan manfaat energi terbarukan

3. Siswa belum bisa merakit instalasi energi terbarukan berupa panell surya

4. Siswa belum mengetahui perawatan panell surya

Adapun tujuan dari pengabdian kemaasyarakat di SMK yaitu

1. Memberikan pengetahuan akan energi terbarukan

2. Memberikan pelatihan pengukuran potensi tenaga surya terhadap beban yang akan digunakan

3. Memberikan pelatihan proses perakitan pembangkit listrik tenaga matahari dan proses pengukuran energi listrik yang dapat dihasilkan oleh panel surya.

\section{METODE}

Metode Kegiatan Pengabdian Masyarakat dalam bentuk pemberian pelatihan tentang edukasi pemanfaatan energi terbarukan dengan melihat potensi sumber daya alam yang ada disekitar dan akan dilaksanakan sebanyak 2 pertemuan. Waktu dan tempat pelaksanaan pengabdian kepada masyarakat yaitu sebagai berikut :

Hari/ tanggal : Jum'at dan Sabtu / 26 dan 27 Juni 2020

Jam

Tempat : 09.00 sampai selesai

Peserta : Siswa kelas XI

Jumlah peserta : 15 siswa

Pengabdian kepada masyarakat dilakukan di SMK Ma'arif NU Talang Kab. Tegal dengan memberikan pelatihan pada siswa SMK Ma'arif NU Talang guna meningkatkan pengetahuan dan keterampilan siswa dalam melakukan perubahan energi terbarukan, dalam hal ini adalah mengkonversi energi matahari menjadi energi listrik dengan menggunakan bantuan alat berupa panel surya. $\begin{array}{ccr}\text { Dalam } & \begin{array}{c}\text { menyelesaikan masalah } \\ \text { dimasyarakat }\end{array} \\ \text { khususnya } & \text { tentang }\end{array}$ pengetahuan dan keterampilan siswa SMK dalam melakukan perubahan energi, perlu adanya sosialisasi dan pelatihan yang dilakukan. Prodi D III Teknik Mesin Politeknik Harapan Bersama tergerak untuk melakukan kegiatan dengan memberikan pelatihan pada siswa di SMK Ma'arif NU Talang tentang proses perubahan energi matahari menjadi energi listrik serta memberikan pelatihan proses instalasi panel surya.

\section{HASIL DAN PEMBAHASAN}

Kegiatan pengabdian pada masyarakat dalam upaya peningkatan pengetahuan energi terbarukan di SMK Ma'arif NU Talang Kabupaten Tegal. Pengabdian masyarakat dilaksanakan dalam 2 hari yaitu pada tanggal 26 Juni 2020 dilaksanakan kontrak kegiatan dengan SMK Ma'arif NU Talang dan persiapan pelatihan. Pada tanggal 27 Juni 2020 dilaksanakan kegiatan sosialisasi dan pelatihan instalasi panel surya, selain itu para siswa juga diberi pelatihan bagaimana cara tegangan dan arus yang keluar dari panel surya.

Kegiatan PKM ini diawali dengan melakukan pre test pada siswa tentang apa yang sudah mereka ketahui tentang konversi energi dan penggunaan alat panel surya.

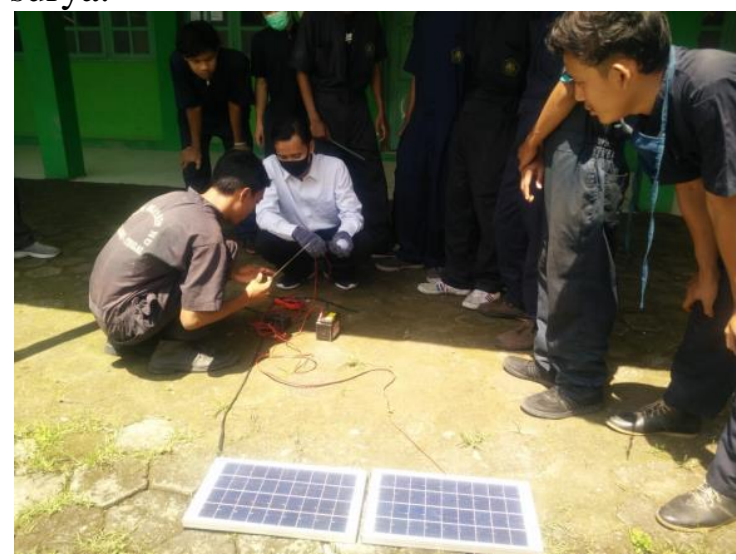

Selanjutnya dilakukan sosialisasi dan pelatihan tentang instalasi panel surya serta penggunaan panel surya baik dari beban 
DC maupun AC.

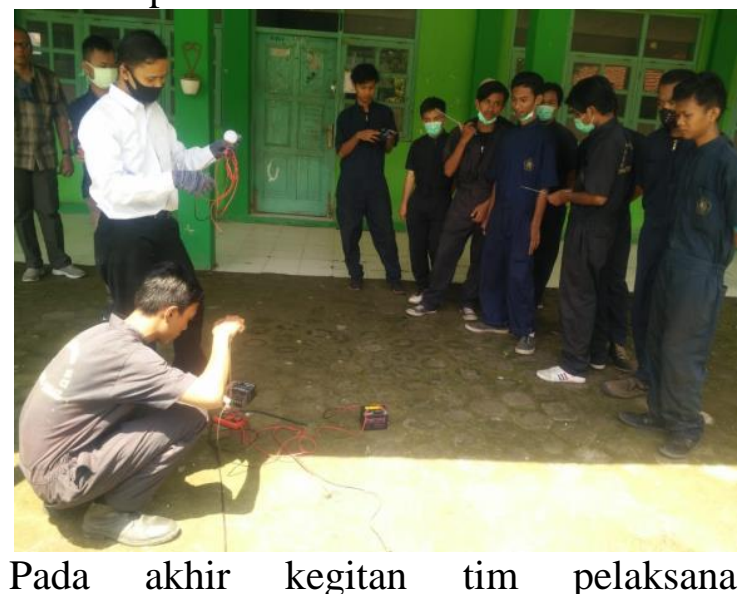

pengabdian pada masyarakat melakukan kegiatan post test untuk mengetahui sejauh mana keberhasilan dari kegiatan yang telah dilaksanakan yaitu dengan meminta para peserta melakukan praktik satu persatu bagaimana cara melakukan instalasi panel surya serta mempraktikkan penggunaan alat pengukur arus dan tegangan.

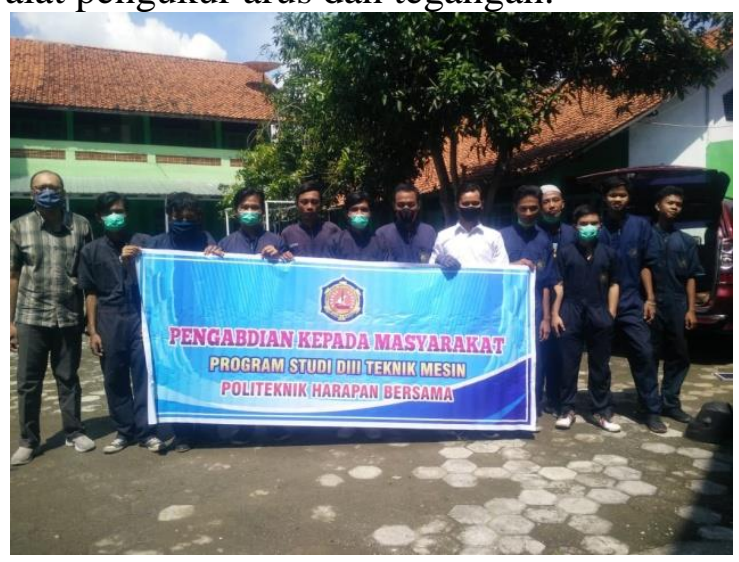

Kegiatan pengabdian masyarakat ini sangat memberikan manfaat bagi siswa di SMK Ma'arif NU Talang karena materi dan pelaitihan yang disampaikan pada pengabdian masyarakat ini adalah materi yang tidak diberikan pada pelajaran yang di sampaikan di SMK Ma'arif NU Talang yaitu konversi energi berupa perubahan energi mastahari menjadi energi listrik. Pada kegiatan pengabdian ini para siswa terlihat antusias untuk mengikuti dan mempraktikkan pelatihan yang diberikan.

\section{PENUTUP}

Hasil pengabdian pada masyarakat dalam bentuk Iptek bagi Masyarakat (IbM) yang telah dilaksanakan dapat disimpulkan sebagai berikut:

1. Terdapat peningkatan pengetahuan siswa SMK tentang konversi energi terbarukan

2. Siswa mampu mempraktikkan instalasi panel surya serta mampu mempraktikkan penggunaan alat ukur arus dan tegangan yang keluar dari panel surya sehingga bisa membuat instalasi panel surya sesuai dengan kebutuhan.

\section{DAFTAR PUSTAKA}

Akhmad, Kholid, 2011, Pembangkit Listrik Tenaga Surya dan Penerapannya Untuk Daerah Terpencil, Jurnal Dinamika Rekayasa, 1(1): 28- 33

Apribowo, C.H.B., 2017, Prototype Sistem Pompa Air Tenaga Surya Untuk Meningkatkan Produktivitas Hasil Pertanian, Jurnal abdimas, universitas negeri semarang. Vol 21. No 2 : 97-102

Anggara, I.W.G.A, Kumara, I.N.S., Giriantari, I.A.D, 2014, Studi Terhadap Unjuk Kerja Pembangkit Listrik Tenaga Surya 1,9 Kw Di Universitas Udayana Bukit Jimbaran, Spektrum, 1(1): 118-122.

Hasan, H., 2012, Perancangan Pembangkit Listrik Tenaga Surya Di Pulau Saugi, Jurnal Riset dan Teknologi Kelautan, 10(2): 169-180.

Ikhsan, 2013, Peningkatan Suhu Modul Dan Daya Keluaran Panel Surya Dengan Menggunakan Reflektor, Jurnal ilmiah Dosen pada Jurusan Fisika Fakultas Sains dan Teknologi UIN Alauddin Makassar. 
Karmiathi, N.M., 2011, Rancang Bangun Modul Solar Cell Dengan Memanfaatkan Komponen Fotovoltaic Kompatibel, Jurnal Logic, 11.

Rahayuningtyas, A., Kuala, S.I., dan Apriyanto, F., 2014, Studi Perencanaan Sistem Pembangkit Listrik Tenaga Surya (Plts) Skala Rumah Sederhana Di Daerah Pedesaan Sebagai Pembangkit Listrik Alternatif Untuk Mendukung Program Ramah Lingkungan Dan Energi Terbarukan, Prosiding SnaPP 2014 Sains, Teknologi, dan Kesehatan, pp. 223-230

Subandi, Slamet Hani, 2015, Pembangkit Listrik Energi Matahari Sebagai Penggerak Pompa Air Dengan Menggunakan Solar Cell, Jurnal Teknologi Technoscientia, 7(2): 157163
Sunaryo, dan Setiono.J, 2014, Analisis Daya Listrik Yang Dihasilkan Panel Surya Ukuran $216 \mathrm{Cm}$ X $121 \mathrm{Cm}$ Berdasarkan Intensitas Cahaya, Jurnal Ilmiah ISSN: 2339-028X Jurusan Teknik Mesin, Fakultas Teknik, Universitas Muhammadiyah Riau.

Ubaidillah, Suyitno, Juwana, Wibawa Endra, 2012, Pengembangan Piranti Hibrid Termoelektrik Sel Surya Sebagai Pembangkit Listrik Rumah Tangga, Jurnal Litbang Provinsi Jawa Tengah, 10(2): 194-211

Widodo, Djoko Adi, Suryono, Tatyantoro A, 2010, Pemberdayaan Energi Matahari Sebagai Energi Listrik Lampu Pengatur Lalu Lintas, Jurnal Teknik Elektro, 2(2): 133-138 